\title{
Influence of Leadership on Job Satisfaction at Selected Government Organizations in Nairobi County
}

\author{
Njoroge, Veronica Wanjiru \\ School of Business, Laikipia University, PO Box 1100-20300 Nyahururu, Kenya \\ Gakobo, Thomas Waweru \\ School of Business, Laikipia University, PO Box 1100-20300 Nyahururu, Kenya \\ Ochieng Isaac \\ School of Business, Laikipia University, PO Box 1100-20300 Nyahururu, Kenya
}

\begin{abstract}
Public organizations in Kenya have become vulnerable to losing their highly qualified, knowledgeable and experienced employees to well-paying public and private organizations. The consequences of losing such employees are dire since public organizations invest heavily on their employees in terms of recruitment, induction, training, development, maintaining and retaining of such employees. This study evaluated the influence of leadership on job satisfaction in selected government organizations in Nairobi County. To achieve this objective, the study was guided by Locke's Value Theory, Maslow Hierarchy of Needs Theory and Herzberg Two Factor Theory. The study employed a descriptive research design. The population of this study was 5850 employees at both managerial and non-managerial positions in Teacher Service Commission, Kenya National Examination Council and Higher Education Loans Board. The sample size was 400 respondents. Data was collected using structured questionnaires. The collected data was analyzed using descriptive and inferential statistics. The response rate was 300 questionnaires representing 80.2\% response rate.Findings established that leadershiphad a good correlation association with job satisfaction $(\mathrm{r}=0.642)$. The results indicated that there was a positive and significant association between leadership and job satisfaction. The study concluded that leadership is a critical element of enhancing job satisfaction among the employees of entities of the Ministry of Education. Thus, the leadership of these organizations should lead by example to inculcate employee job satisfaction.
\end{abstract}

Keywords: Leadership, Job Satisfaction, Government organization, Nairobi County

DOI: $10.7176 / \mathrm{EJBM} / 13-12-06$

Publication date:June $30^{\text {th }} 2021$

\section{Introduction}

The concept of job satisfaction deals with the level of contentment of an individual in the workplace. Tungkiatsilp (2013) in a study on job characteristics and job satisfaction in India argued that the state of positive attitude of an employee towards their job constitutes job satisfaction. The definition looks at job satisfaction as an individual attitude towards the job as shown from their feelings, beliefs and behaviours. An individual with a high level of job satisfaction has positive behaviour towards the job while one who is dissatisfied has negative tendencies towards the stated job.

Studies related to the concept of job satisfaction may be traced way back in the industrial revolution in the United States of America (USA). Majority of the earlier global studies dealt with the aspect of maximizing the input of workers during the scientific management era (Unutmaz, 2014: Redman \& Snape, 2010, 2010; Mullins, 2005). During this period, Fredrick Taylor put emphasis on employee's relations and methodologies of undertaking employee training (Bono, Glomb, Shen, Kim \& Koch, 2013). Taylor hypothesized that to increase employee productivity, there was need to lay emphasis on clarity of assigned daily tasks, standardization of conditions of work, and high remuneration for achieved tasks. These studies began to take new direction when (Elton Mayo, 2010) focused on the positive and negative reactions towards the job through the study of effect of lighting on employee performance (Kabir, 2011). (Elton Mayo, 2010) later introduced other factors such as temperature, fatigues, working time and breaks as inducement for enhanced performance. Through studying employees and provision of more attention in their workplace, their motivation and performance was enhanced by studies led by Mayo. Employee job performance continued to improve because of the uniqueness of the situation of employee job satisfaction studies (Sadri \& Bowen, 2011; Luthans, 2005). Other researchers have continued to offer more emphasis that satisfied employees are more productive in the workplaces (Kabir, 2011; Kawada, Tomoyuki, \& Otsuka, Toshiaki, 2011).A snapshot reveals that in Kenya different authors have conducted studies on varying aspects of job satisfaction. Seggawa (2014) in a study on influence of employee job satisfaction on performance noted that intrinsic factors like level of responsibility at work, recognition, work meaningfulness and the extent to which employees believe their work has a significant contribution to job satisfaction. Njiru (2014) showed that employee dissatisfaction was brought about by inadequate remuneration, 
poor working environment, rigid leadership styles, too much workload, poor academic performance, lack of promotion opportunities, poor interpersonal relations and inadequate teaching equipment and resources. Kinyua (2014) on a study on job satisfaction amongst teachers stated that factors influencing job dissatisfaction included poor leadership, special allowance, the physical facilities, procurement of resources, work environment, teaching and learning materials, current salaries and slim promotion opportunities.

The increasing level of job dissatisfaction among employees within the public organizations in Kenya needs to be addressed since it affects the performance of these organizations (Agoi, 2015). Rahman, Akhter and Khan (2017) stated that dissatisfied employees is the leading cause of poor performance amongst organizations. Kawada et al. (2011) and Khalid et al. (2012) stated that job characteristics, work environment, leadership, benefits and employee demographic factors are crucial in understanding job satisfaction. As suggested by Kawada et al. (2011) and Khalid et al. (2012) few local studies have focused on job characteristics, work environment, leadership, benefits and employee demographic factors as crucial determinants of job satisfaction in public organizations. Indeed, Ssegawa had also recommended for the need for a study on high turnover in public organizations in Kenya. Therefore, the researcher sought to bridge the knowledge through an in-depth examination on influence of leadership on job satisfaction at TSC, KNEC and HELB in Nairobi.

\section{Literature Review}

Redman and Snape (2015) defined leadership as a process of interaction between leaders and employees in which a leader tries to influence the behavior of employees to achieve organizational goals. Organizational leadership at all levels has to input their efforts in ensuring that employees are guided and equipment with the necessary leadership and equipment to undertake their work adequately. Buford (2011) identified poor leadership as a major reason for low morale and unsatisfactory employee performance, yet organizations are usually tempted to promoting employees' to management and leadership roles without assessing their readiness to the roles and neglecting provision of sufficient orientation and training. When making decisions to choose managers it is worth noting that although one might be a stellar performer in their area of expertise, they rarely automatically possess the skills knowledge, and abilities to perform at the same level as managers and leaders. This means for organizations to succeed in selecting the right managers they have to take time to use evaluation tools such as behavioral interviews or psychological assessments to identify the right managers (Govender \& Parumasur, 2010). Guest (2010) noted that relations between managers and employees have a significant effect on organization performance and job satisfaction. Bad relations often lead to violations of psychological contract, low levels of fulfillment of perceived promises and commitments made by the organization. Quality supervision requires one to have good leadership qualities. Bosses are expected to be in tune to their people. Golshan, Kaswuri and Agashahi, 2010) noted that leaders are expected to take charge effectively of the team they lead. It is also important for them to boost performance by watching their peoples back: making it safe for them to learn, act and take intelligent risks; shielding them from unnecessary distractions and external idiocy and doing hundreds of little things that help them achieve one small win after the other and feel pride and dignity along the way. Leadership through supervision or management plays a pivotal role relating to job satisfaction in terms of the ability of the supervisor or manager to provide emotional support and technical guidance with job related tasks (Robbins et al., 2003). According to Kemboi (2016), transformational leadership theory emphasizes the importance of leaders inspiring subordinates admiration, dedication and unquestioned loyalty through articulating a clear and compelling vision. Transformational leadership is a model which comprise four attributes; intellectual stimulation, individualized consideration, idealized influence and inspiration motivation. On the other hand, Allen et al., (2000) proposed that mentoring by supervisors in order to build a mutual understanding and relationship in between the supervisor and the employees. This in effect will create a mutual satisfaction between employee and supervisor to enhance organization performance. The mentoring is used for developmentorientation while on the other hand non-supervisory mentor may increase mentee's confidence by providing access to outside organization (Scandura \& Williams, 2004). When a supervisor provides mentoring, the relationship affects the protégés skill development and intentions to remain with the employer. Familiarity with the characteristics of people orientations towards work and communication has many consequences for forecasting behavior in the organizational setting (McCroskey et al., 2004b). Perhaps this explains why recognizing and knowing what to expect from supervisors allows employees to better adapt and change their communication behaviors. Furthermore, the communicative association between the supervisor and their juniors has substantial potential to affect the satisfaction of both parties (McCroskey et al. 2005). Generally, high levels of supervisor friendliness, emotional strength and extraversion connected to subordinate satisfaction with a supervisor. Chen et al. (2005) surveyed 18 of Taiwan's higher education nursing schools that had a minimum of 20 full-time faculty members. The survey found out that idealized consideration, a transformational leadership factor, and contingent reward, a transactional leadership factor, were positively significant predictors of faculty job satisfaction. Public sector organizations like TSC, HELB and KNEC are claimed to lack job intrinsic factors like freedom, involvement in decision making, interesting work activities, role clarity and task significance 
(Graham and Hays, 1993). Skilled leaders in organization are thus vital in addressing intrinsic job factors to promote job satisfaction.

\section{Methodology}

The study employed a descriptive research design. The descriptive survey design was chosen because the objective of the study is to describe, explain and validate generalizable findings. The researcher found it appropriate that a descriptive research design was appropriate for this study since this study was concerned with assessing the influence leadership on job satisfaction in the selected government organization in Nairobi County, Kenya. Ssegawa (2014) also used descriptive survey design in a similar study on factors influencing employee job satisfaction and its impact on employee performance: a case of Unilever Kenya. This study focused on three government organization (KNEC, TSC and HELB) with a targeted population of 5,835 managerial and nonmanagerial employees of these organizations. Various sampling techniques were used in this study. First, purposive sampling was used to select three government organizations (KNEC, TSC and HELB). Orodho (2009) defines purposive sampling as the technique that statistically select study samples by the way of certain set criteria. The three organizations were purposively selected since they have the largest number of employees under the Ministry of Education. Secondly, stratified sampling technique was used to create three strata of the population of the three organizations. Thirdly, proportionate stratified sampling was used to select representative samples of employees from each of the three strata and also samples of managerial and non-managerial staff in the three organizations. Finally, to select the individual respondents, the study used Yamane (1967) sample size formula arriving at a sample size of 374 . The study used self-administered questionnaires to collect data from the respondents. A pilot test was conducted to assist in determining if there were flaws, limitations, or other difficulties in filling the questionnaires. To test the reliability of the research instrument, the study used the Cronbach Alpha rule of thumb that states that if the Cronbach values of the items to be included in the study should not be lower than 0.7 (Cronbach, 2004). Validity of the instrument was tested using the content and construct validity. Content validity refers to the degree that the instrument covers the content that it is supposed to measure (Creswell, 2014). To validate the questionnaires, the study adopted face validity which is a form of content validity. This involved guidance from the supervisors using reviews and comments on the content to enhance the quality of the instruments. The study employed a pick and drop method to administer the questionnaire to the respondents where the respondents were able to pick them from a visible central points and drop them after filling at a strategic place. Data was analyzed using two methods namely descriptive and inferential analysis.

\section{Results and Discussions}

From the descriptive analysis, majority $(72 \%)$ were in agreement that the leadership skills from their supervisor sometimes and/or often guides them in performing their job while $33.3 \%$ were of the opinion that the leadership knowledge of their managers often enables them to successfully complete tasks. In addition, 55\% agreed that the leadership experience of their supervisor always motivates them to successfully perform duties with $33.3 \%$ stating that communications sometimes seems good within this organization. Further, $64.4 \%$ said that supervisors sometimes encourage them to be their best through guidance. Finally, 52.2\% said that senior managers sometimes visibly demonstrate a transformational leadership. Table 4.3 gives a description of the responses on leadership description. The findings complement Guest (2010) statement that relations between managers and employees have a significant effect on organization performance and job satisfaction. It also support Robbins et al. (2003) that leadership through supervision or management plays a pivotal role relating to job satisfaction in terms of the ability of the supervisor or manager to provide emotional support and technical guidance with job related tasks. The implication is that the skills and experience levels of the management of TSC, HELB and KNEC play a pivotal role in inculcating employee job satisfaction.Before the inferential analysis, a number of diagnostic tests were conducted. Reliability Analysis was conducted to ensure the internal consistency of the items of the variables. This was assessed using Cronbach's Alpha where the Cronbach's Alpha values of leadership was 0.806 indicating a good subscale reliability.Normality test was also undertaken to test the Skewness and kurtosis in order to measure normality test. Normality ranges from $-1.0-+1.0$ under the kurtosis and skewness values. The values of skewness and kurtosis indices did not exceed the absolute values of 1 and, therefore, the data set was considered to follow normal distribution and consequently the relationship would be tested using multiple linear regressions. Finally ccorrelation analysis was undertaken using Pearson Correlation Coefficient ( $r$ ) with scores of +1 to -1 . Leadership was found to be positive and significantly related to job satisfaction $(\mathrm{r}=0.642$, $\mathrm{p}$-value $=0.000<0.05)$. This shows that leadership had the good association with job satisfaction. The objective of the study was to assess the influence of leadership on job satisfactions at government organization in the ministry of education in Kenya. The study findings of the model summary of leadership and job satisfaction in Table 1 showed that the coefficient of determination (R2)was 0.527 which implies that leadership explained 52.7 percent of the variations in job satisfaction of employee in these 
organizations.

Table 1.0 Model summary

\begin{tabular}{|c|c|c|c|c|}
\hline Model & $\mathbf{R}$ & R Square & Adjusted R Square & $\begin{array}{l}\text { Std. Error of the } \\
\text { Estimate }\end{array}$ \\
\hline 1 & $.726^{\mathrm{a}}$ & .527 & .445 & .638 \\
\hline
\end{tabular}

a. Predictors: (Constant), Leadership

b. Dependent Variable: Job satisfaction

In the analysis of variance (ANOVA) statistics of leadership in Table 2, the F-value was 6.4449 and the pvalue was 0.000 . These results showed that the influence between leadership and job satisfaction was significant with p-values less than 0.05 at $\alpha=0.05$ level.

Table 2.0 Analysis of Variance (ANOVA)

\begin{tabular}{llrrrr}
\hline Model & & Sum of Squares & Mean Square & F & Sig. \\
\hline 1 & Regression & 13.112 & 2.622 & 6.449 & $.000^{\mathrm{a}}$ \\
& Residual & 11.792 & .407 & & \\
& Total & 24.904 & & & \\
\hline
\end{tabular}

a. Predictors: (Constant), Leadership

b. Dependent Variable: Job satisfaction

The null hypothesis was that of this study was that Leadership has no statistical significance on job satisfaction in selected government organizations in Nairobi County.Results in table 4.16 had shown positive and significant association in leadership and job satisfaction since $\beta=.728, t=4.449, p<.05$. This led to the rejection of the null hypothesis and acceptance of alternate hypothesis that there is a significance influence of leadership and job satisfaction. Since estimation of regression of leadership was 0.728 , the imperative is that it contributed $72.8 \%$ of job satisfaction. The findings support Wright and Davis (2003) who established that leadership is the most critical factor for enhancing employee job satisfaction in public organizations.

\section{Conclusion}

The objective of the study was to assess the influence of leadership on job satisfaction at government organizations in the ministry of education. The findings of descriptive analysis revealed that majority $(72 \%)$ were in agreement that the leadership skills from their supervisor sometimes and/or often guides them in performing their job. In addition, 55\% agreed that the leadership experience of their supervisor always motivates them to successfully perform duties. Further, $64.4 \%$ said that supervisors sometimes encourage them to be their best through guidance. The findings support Robbins et al. (2003) that leadership through supervision or management plays a pivotal role relating to job satisfaction in terms of the ability of the supervisor or manager to provide emotional support and technical guidance with job related tasks. The implication is that the skills and experience levels of the management of TSC, HELB and KNEC play a pivotal role in inculcating employee job satisfaction. Findings on the influence of leadership on job satisfaction revealed that $67.8 \%$ of respondents stated that they often do not intend to leave the job due to motivation from the experienced supervisor. The findings agree with Golshan, Kaswuri and Agashahi (2010) who noted that leaders through supervision or management plays a pivotal role relating to job satisfaction in terms of the ability of the supervisor or manager to provide emotional support and technical guidance with job related tasks. The reality of the findings is that organization leaders in TSC, KNEC and HELB are important in inspiring employees' admiration, dedication and unquestioned loyalty and the totality of job satisfaction. Findings of inferential statistics showed that leadershiphad the best association with job satisfaction $\left(\mathrm{r}^{2}=0.642\right)$. Therefore, there was a positive and significant association between leadership and job satisfaction. This led to the rejection of the null hypothesis and acceptance of alternate hypothesis that there is a significance influence of leadership and job satisfaction. Since estimation of regression of leadership was 0.728 , the imperative is that it contributed $72.8 \%$ of job satisfaction.

\section{Recommendation}

The study established that leadership had a good association with job satisfaction. Therefore, the study concluded that leadership is a critical element of enhancing job satisfaction among the employees of entities of the Ministry of Education. Thus, the leadership of these organizations should lead by example to inculcate employee job satisfaction.

\section{References}

Abdulla, J., Djebarni, R., \&Mellahi, K. (2011). Determinants of job satisfaction in the UAE: A case study of the Dubai police. Personnel review, 40(1), 126-146. 
Abwavo, B. A. K. (2005). The Psychological Contract, Organizational Commitment and Job Satisfaction: A study of Commercial Banks in Nairobi, Unpublished MBA Project, University of Nairobi.

Achieng,' O. S. (2013). Job satisfaction and employee performance within the telecommunication industry in Kenya: A case of Airtel Kenya Limited (doctoral dissertation, Kenyatta University). Retrieved from http://etd-library.ku.ac.ke/handle/123456789/10135 (Accessed on June 6th 2016 at 9:20 am)

Agoi, L.F. (2015). Effect of Work Engagement on Employee Turnover Intention in Public Sector, Kenya.International Journal of Economics, Commerce and Management United Kingdom, 3 (12), 1-2.

Allen, T. D., Herst, D. E., Bruck, C. S., \& Sutton, M. (2000). Consequences associated with work-to-family conflict: a review and agenda for future research. Journal of occupational health psychology, 5(2), 278.

Alsemeri, H. A. (2016). Factors affecting job satisfaction: An empirical study in the public sector of Saudi Arabia (Doctoral dissertation, Victoria University).

Ambasa, A. (2014). Factors affecting employee job satisfaction in institutions of higher education in Kenya: A case study of United States International University (USIU). Unpublished MBA Project, USIU.

Appiah-Agyekum, N. N., \&Peprah, R. H. S. S. O. (2013).Determinants of Job Satisfaction among Ghanaian Teachers.Journal of Education and Practice, 4(3), 43-50.

Armstrong, M (2006). A handbook of human resource management practice, (10 $\left.{ }^{\text {th }} \mathrm{ed}.\right)$. London, UK: Kogan Page.

Asegid, A., Belachew, T., \&Yimam, E. (2014). Factors influencing job satisfaction and anticipated turnover among nurses in Sidama zone public health facilities, South Ethiopia. Nursing research and practice, 2014.

Avdija, A. S., \& Roy, S. (2013). The effects of emotional exhaustion on prison employees' job satisfaction and personal accomplishments. International Journal of Criminology and Sociological Theory, 6 (4).

Babbie, E. (2004).The Practice of Social Research (10 ${ }^{\text {th }}$ ed.). Belmont, CA: Thomson Learning.

Bell, R.C., \& Weaver, J .R. (1987). The dimensionality and scaling of job satisfaction: An internal validation of the Worker Opinion Survey. Journal of Occupational Psychology), 60, 147 - 55.

Bernstein, D.A. \& Nash, P.W. (4th Ed.).(2008). Essentials of psychology. Boston, IL: Houghton Mifflin Company.

Bhatnagar, A. (2014). Determinants of motivation and job satisfaction among primary health workers: case studies from Nigeria and India (Doctoral dissertation).

Bless, C., Higson-Smith, C. \&Kagee, A. (2016). Fundamentals of social research methods: An African perspective. Cape Town: Juta.

Bono, J. E., Glomb, T. M., Shen, W., Kim, E., \& Koch, A. J. (2013). Building positive resources: Effects of positive events and positive reflection on work stress and health.Academy of Management Journal, 56(6), $1601-1627$.

Blaauw, D., Ditlopo, P., Maseko, F., Chirwa, M., Mwisongo, A., Bidwell, P., ...\& Normand, C. (2013). Comparing the job satisfaction and intention to leave of different categories of health workers in Tanzania, Malawi, and South Africa.Global health action, 6(1), 19287.

Brainard, J. (2005). Postdoctoral researcher's value structured training over pay, survey says. The Chronicle of Higher Education, 51(32), p. 21.

Bryman, A. \& Bell, E. (2007).Business Research Methods, Third edition, Oxford University Press.

Bryman, A., \& Bell, E. (2015).Business Research Methods. Oxford University Press, USA.

Buford, S. (2006) Linking Human Resources to Organizational Performance and Employee Relations in Human Service Organizations: Ten HR Essentials for Managers, Routledge London UK.

Buker, H. \&Dolu O. (2010). Police job satisfaction in Turkey: Effects of demographic, organizational and jurisdictional factors. International Journal of Comparatives and Applied Criminal Justice, 34, (1), 1-7.

Butler, M. \& Rose, E. (2011).Introduction to organizational behaviour, (Edited) London, UK: Chartered Institute of Personnel \& Development.

Caers, R., Du Bois, C., Jegers, M., De Gieter S., De Cooman, R., Pepermans, R. (2008).Measuring community nurses 'Icfai University Press.From < http:// www.Iupindia.org $>$ (Retrieved May 15, 2016).

Cao, H., Jiang, J., Oh, L. B., Li, H., Liao, X., \& Chen, Z. (2013). A Maslow's hierarchy of needs analysis of social networking services continuance. Journal of Service Management, 24(2), 170-190.

Chebet, J. (2015). Determinants of Employees' Performance in the County Governments of Kenya: A Case of Bungoma County (Doctoral dissertation, University of Nairobi).

Chen, K.J., \& Chen, S.I. (2008).Personal traits and leadership styles of Taiwan's higher educational institution in innovative operations.American Academy of Business Cambridge, 12 (2), 145-150.

Clement-Croome, D. (2006).Creating the productive workplace ( $2^{\text {nd }}$ ed.). Oxford, England: Taylor and Francis.

Cohen, A. \& Keren, D. (2008), Individual Values and Social Exchange Variables: Examining Their Relationship to and Mutual Effect on In-Role Performance and Organizational Citizenship Behaviour. Group and Organization Management 33(4), 425-452.

Cooper, C.R., \& Schindler, P.S. (2008).Business research methods (10 ${ }^{\text {th }}$ ed.). Boston: McGraw-Hill. 
Cooper, D.R. \& Schindler, P.S. (2014).Business Research Methods (9th Ed.). New York, USA: The Irwin/McGraw-Hill Series.

Creswell, J. W. (2014). Research Design: Qualitative, Quantitative, and Mixed Methods Approaches. Los Angeles: SAGE Publication.

Cronbach, A. (2004).Cronbach's Alpha: Considering Confirmatory Factor Analysis and Segmentation. Journal of Statistics, 16 (2), 142-148.

Danish, R.Q., \& Usman, A., (2010).Impact of Reward and Recognition on Job Satisfaction and Motivation: An Empirical Study from Pakistan. International Journal of Business \& Management, 5(2).

Dartey-Baah, K., \&Amoako, G. K. (2011). Application of Frederick H erzberg's Two-Factor theory in assessing and understanding employee motivation at work: a Ghanaian Perspective. European Journal of Business and Management, 3(9), 1-8.

Dugguh, S., \& Dennis, A. (2014).Job satisfaction theories.Traceability to employee performance in organizations. Journal of Business and Management, 16(5), 11-18. Retrieved from http://www.iosrjournals.org/iosr-jbm/papers/Vol16-issue5/Version-1/C016511118.pdf (accessed on May $11,2016$ at $10.00 \mathrm{am})$

Durst, S. L., \& DeSantis, V. S. (1997).The determinants of job satisfaction among federal, state, and local government employees. State \& Local Government Review, 7-16. (accessed on May 9, 2016 at 12.15 pm)

Ellickson, M. C., \& Logsdon, K. (2002).Determinants of job satisfaction of municipal government employees. Public Personnel Management, 31(3), 343-358.

Elton, Mayo (2010). The Management Theory

Ewen, R. B. (1964). Some determinants of job satisfaction: A study of the generality of Herzberg's theory. Journal of Applied Psychology, 48 (3), 161.

Faragher, E.B., Cass, M., \& Cooper, C.L. (2005).The relationship between job satisfaction and health: A metaanalysis.Occupational and environmental medicine, 62(2), 105-112.

Foster, J. (2000). Motivation in the workplace, in Chiem, N. (Ed.), Introduction to Work and Organizational Psychology, Blackwell, Oxford, pp. 302-26.

Garbie, I.H. (2014). An experimental study on Assembly work station considering Ergonomically Issues. In proceedings of the 41 st International conference on Computers \& Industrial Engineering.

Garland, B. E., McCarty W.P., \& Zhao, R.(2009).Job Satisfaction and Organizational Commitment In Prisons: An examination of psychological staff, teachers, and unit management staff. Journal of Criminal Justice and Behavior, 36, 163-183.

Golshan .N, Kaswuri. H, Agashahi B. (2011). Effects of Motivational Factors on Job Satisfaction: An Empirical Study on Malaysian Gen-Y Administrative and Diplomatic Officer: International Conference on Advanced Management Science. IACSIT Press, Singapore.

Govender, S. \&Parumasur, S.B. (2010).The relationship between employee motivation and job involvement. School of Management Studies, University of KwaZulu-Natal.

Hackman, J. R., \& Oldham, G. R. (1975).Development of the job diagnostic survey.Journal of Applied psychology, 60 (2), 159.Retrieved from: http://psycnet.apa.org/journals/apl/60/2/159/ (Accessed on April 3, 2017 at $10.45 \mathrm{am})$.

Hackman, J.R. \& Oldham, G.R. (1976), Motivation through the Design of Work: Test of a Theory, Organizational Behaviour and Human Performance 16 (2), 250-279.

Hanaysha, J., \& Tahir, P. R. (2016).Examining the effects of employee empowerment, teamwork, and employee training on job satisfaction.Procedia-Social and Behavioral Sciences, 219, 272-282.

Herzberg, F. (1974), Motivation-Hygiene Profiles: Pinpointing What Ails the Organization, Organizational Dynamics. 3(2), 18-29.

Herzberg, F., Mausner, B. \& Snyderman, B. (1959).The Motivation to Work. New York City, NY: Wiley.

Hussin, A. B. (2011). The relationship between job satisfaction and job satisfaction and job performance.Centre for graduate studies; Open University Malaysia.

Iqbal, A. (2010). An empirical assessment of demographic factors, organizational ranks and organizational commitment.International Journal of Business and Management, 5(3):16-27.

Javed, M., Balouch, R., \& Hassan, F. (2014).Determinants of job satisfaction and its impact on employee performance and turnover intentions.International journal of learning and development, 4(2), 120-140.

Kabir, M. (2011), Factors affecting employee job satisfaction of pharmaceutical sector, Australian Journal of Business and Management Research, 1 (9), 113-123.

Kafyeta, S. A. (2015). Factors Influencing Employees' Job Satisfaction In Public Organizations In Tanzania: A Case of Tanzania Electric Supply Company (TANESCO) Limited in Dar es Salaam (Doctoral dissertation, The Open University Of Tanzania).

Katsikea, E., Theodosiou, M., Perdikis, N., \&Kehagias, J. (2011). The effects of organizational structure and job characteristics on export sales managers' job satisfaction and organizational commitment. Journal of World 
Business, 46(2), 221-233.

Kaur, A. (2013). Maslow's need hierarchy theory: Applications and criticisms. Global Journal of Management and Business Studies, 3(10), 1061-1064.

Kawada, Tomoyuki, \& Otsuka, Toshiaki (2011).Relationship Between Job Stress, Occupational Position and Job Satisfaction Using a Brief Job Stress Questionnaire. Work, (40), 393-399

Kemboi, P. C. (2016). Determinants of employee job satisfaction in public security sector in Kenya: A case of National Police Service. Strategic Journal of Business \& Change Management, 3(2) 659-688.

Khalid, S., Irshad, M. Z., \& Mahmood, B. (2012). Job satisfaction among academic staff: A comparative analysis between public and private sector universities of Punjab, Pakistan. International Journal of Business and Management, 7(1), 126.

Khalilzadeh, J., Del Chiappa, G., Jafari, J., \&ZarghamBorujeni, H. (2013). Methodological approaches to job satisfaction measurement in hospitality firms. International Journal of Contemporary Hospitality Management, 25(6), 865-882 Retrieved from: http:/www.emeraldinsight.com/doi/full/10.1108/IJCHM-052012-0067 (Accessed on March, 1st 2017 at 2:24 pm)

Kim, H.K (2014). Work-life Balance and Performance: The Meditating Role of Affective Commitment. Global business and management research: an international journal, 6(37-51..

Kinyua, B. M. (2014). Determinants of Job Satisfaction among Teachers of Learners with Special Educational Needs in Integrated Public Primary Schools in Kirinyaga County, Kenya.

Kombo, K., \& Tromp, L. (2006).Proposal and thesis writing-an introduction. Nairobi. Pauline's Publications.

Korir, S. C., Rotich, J., \& Bengat, J. (2015).Performance Management and Public Service Delivery in Kenya.European Journal of Research and Reflection in Management Sciences, 3 (4). Retrieved from http://www.idpublications.org/wp-content/uploads/2015/05/Performance-Management-and-Public-ServiceDelivery-in-Kenya.pdf (Accessed on June 6th 2016 at 11:45 am)

Kothari, C.R. (2004). Research methodology methods and technique (2 $\left.{ }^{\text {nd }} E d\right)$.New Delhi, New age International ltd.

Kuria, E. N. (2011). Factors influencing the level of job satisfaction of the deputy head teachers of the public secondary schools in Kenya (Doctoral dissertation). Retrieved from http://etdlibrary.ku.ac.ke/handle/123456789/938 (Accessed on June 6th 2016 at 9:50 am).

Kyongo, J. K. (2011) Factors influencing jobs satisfaction among public health employees of local authorities in Kenya. case of the city council of Nairobi. Retrieved from http://etdlibrary.ku.ac.ke/handle/123456789/1941 (Accessed on June 6th 2016 at 8:52 am).

Leaman, A., Thomas, L. and Vandenberg, M. (2007) 'Green' buildings: what Australian building users are saying, EcoLibrium, 6, 22-30.

Locke, E.A (1976).The nature and causes of job satisfaction. In Dunette, M D. (ed) Handbook of Industrial and organization psychology. Chicago, IL: RanMcNally pp. 1297-1350.

Locke, E.A. (1980). The Nature and Causes of Job Satisfaction. M.D Dunnette (Ed.), Handbook of Industrial and Organizational Psychology, Chicago, Rand McNally. pp.1297-1349.

Lundberg, C., Gudmundson, A., \& Andersson, T. D. (2009). Herzberg's Two-Factor Theory of work motivation tested empirically on seasonal workers in hospitality and tourism. Tourism management, 30(6), 890-899.

Luthans, F. (2005).Organizational Behavior (10th ed). New Yolk, McGraw-Hill Irwin

Malhotra, J. L. (2016). An Evaluation of the Determinants of Job Satisfaction in Canadian Family Physicians.

Maslow, A., (1995). Motivation and Personality. New York City, NY: Harper.

Maslow, A.H. (1943). A Theory of Human Motivation, Psychological Review 50, 370-396.

McCroskey, L.L., McCroskey, J.C., \& Richmond, V.P. (2005). Applying organizational orientations theory to employees of profit and non-profit organizations. Communication Quarterly, 53, 21-40.

McFarlin, D. B., \& Sweeney, P. D. (1992). Distributive and procedural justice as predictors of McFarlin, D. B., \& Sweeney, P. D. (1992). Distributive and procedural justice as predictors of

Mitchell, V.F. \&Moudgill, P. (1976), Measurement of Maslow's Need Hierarchy. Journal of Organizational Behaviour and Human Performance 16 (2), 334-349.

Moorhead, G. \&GrifCin, R. (2004).Organizational Behaviour: Managing People and Organizations, ( $7^{\text {th }}$ ed) Boston, Houghton Mifflin Company (Moorhead \& Griffin, 1989).

Morris, M. G., \&Venkatesh, V. (2010). Job characteristics and job satisfaction: understanding the role of enterprise resource planning system implementation. Mis Quarterly, 143-161.

Morris, M. G., \&Venkatesh, V. (2010). Job characteristics and job satisfaction: understanding the role of enterprise resource planning system implementation. Mis Quarterly, 143-161.

Mullins, J.L. (2005). Management and organizational behavior $\left(7^{\text {th }}\right.$ ed.). New York City, NY: Pearson Education Limited, Essex, p. 700.

Munir, R. I. S., \& Rahman, R. A. (2016).Determining dimensions of Job Satisfaction using factor analysis.Procedia Economics and Finance, 37, 488-496. 
Mutiso, C., \&Kilika, J. M. (2017).Using Human Resource Management Practices to Predict Quality Service Delivery: Case of Public Secondary Schools in Kenya.International Journal of Business and Management, 12(10), 121.

Nandwa, A. D. (2012). Factors influencing job satisfaction among public primary schools teachers in Kenya: A case of Mombasa municipality (Doctoral dissertation). (accessed on May 9, 2016 at $11.45 \mathrm{am}$ ).

Ng'ethe, J.M., Namusonge, G.S \& Mike, A.I. (2012). Influence of Leadership styles on Academic staff R Retention in Public Universities in Kenya. International Journal of Business social science, 3(21), 297-302.

Nigam, S. (2017). Factors Affecting job Satisfaction An Analytical Study of Academician in Selected Provate Universities of Central India.

Njiru, L.M. (2014). Job satisfaction and motivation among teachers of Kiharu District in Kenya.Journal of Social Sciences, 5(5), 135-152.

Okoth, L. A. (2003). A Survey of the Factors that Determine the Level of Job Satisfaction among Teachers in Top Ranking Private Schools in Nairobi, Unpublished MBA Project, University of Nairobi.

Ombima, H. P. A. (2014). Factors affecting employee job satisfaction in institutions of higher education in Kenya: A case study of United States international University (USIU) (Masters dissertation, United States International University-Africa). Retrieved from http://erepo.usiu. ac.ke/handle/11732/87. Accessed on April 6th 2017 at 10.33 am.

Orodho, A.J. (2009). Research Methods, Nairobi: Kenyatta University, institute of open learning.

Oyewobi, L. O., Suleiman, B., \& Muhammad-Jamil, A. (2012). Job satisfaction and job commitment: A study of quantity surveyors in Nigerian Public Service. International Journal of Business and Management, 7(5), 179.

Rahman, K. U., Akhter, W., \& Khan, S. U. (2017). Factors affecting employee job satisfaction: A comparative study of conventional and Islamic insurance. Cogent Business \& Management, 4(1), 1273082.

Raziq, A., \&Maulabakhsh, R. (2015).Impact of working environment on job satisfaction.Procedia Economics and Finance, 23, 717-725.

Redman, T., \& Snape, E. (2010). HRM Practices, Organizational Citizenship Behavior, and Performance: A Multilevel Analysis, Journal of management studies 47 (1), 2-4.

Reiner, M.D. and Zhao, J. (1999).The determinants of job satisfaction among United States Air Force's security police. Review of Public Personnel Administration, 19 (3) 5-18.

Republic of Kenya (2016).Electronic Project Monitoring information system.Development Projects in Kenya. Nairobi, Kenya.

Republic Of Kenya, (2007).Kenya Vision 2030. Ministry of State for Planning, National Development And Vision 2030. Nairobi, Kenya: Government Printers satisfaction with personal and organizational outcomes. Academy of Management Journal,2 (1), 34.

Sadri, G., \& Bowen, C. R. (2011). Meeting employee requirements: Maslow's hierarchy of needs is still a reliable guide to motivating staff. Industrial engineer, 43(10), 44-49.

Saunders, M., Lewis, P. \& Thornhill, A. (2009).Research Methods for Business Students.London: St. Martin Press, Inc.

Saunders, M., Lewis, P. \& Thornhill, A. (2012).Research Methods for Business Students $6^{\text {th }}$ Ed.). Pearson Education Limited.

Scanduraa, T.A. \& Williams, E.A. (2004). Mentoring and transformational leadership: The role of supervisory career mentoring. Journal of Vocational Behaviour, 65: 448-468.

Ssegawa, G. (2014). Factors Influencing Employee Job Satisfaction and Its Impact On Employee Performance: A Case of Unilever Kenya (Doctoral dissertation, United States International University Africa).

Sekaran, U. \&Bougie, R., (2009).Research methods for business: a skill building approach. New York: John Wiley \& Sons.

Sekaran, U., \&Bougie, R. (2013).Research Methods for Business. Chennai: Wiley \& sons press.

Shafie, A. \&Khalajasadi, S. (2010). The survey of relationship between job satisfaction and mental health in university employees.Journal of Industrial-Organizational Psychology News, 1. (2), 10-12.

Sikowo, D.C., Namusonge, G.S., Makokha, E.N., Nyagechi, A.K. (2016).Determinants of Employee Satisfaction on Organizational Performance: A Survey of Trans Nzoia County Government. International Journal of Academic Research in Business and Social Sciences, 6, (10), 77-78.

Spector, P.E (1997). Job Satisfaction: Application, assessment, causes and consequences. Thousand Oaks, CA: SAGE.

Ssegawa, G. (2014). Factors Influencing Employee Job Satisfaction and Its Impact On Employee Performance: A Case of Unilever Kenya (Doctoral dissertation, United States International University Africa).

Steijn, B. (2004). Human resource management and job satisfaction in the Dutch public sector. Review of Public Personnel Administration, 24(4), 291-303 (accessed on May 9, 2016 at $11.25 \mathrm{am}$ ).

Stello, C. M. (2011). Herzberg's two-factor theory of job satisfaction: An integrative literature review. In 
Unpublished paper presented at The 2011 Student Research Conference: Exploring Opportunities in Research, Policy, and Practice, University of Minnesota Department of Organizational Leadership, Policy and Development, Minneapolis, MN.

Sweeney, P.D. \&McFarlin, D.B. (2005).Organizational Behavior, Solutions for Management.New York City, NY: McGraw-Hill/Irwin

Tabatabaei, S. \&Gharanjiki, B.(2011). The relationship between stress related to work and job satisfaction with work shifts and hours of Hormozgan Cement Factory employees. Journal of Healthy Work, 4 (14 \& 15), $42-48$.

Tanjeen, E. (2013). A study on factors affecting job satisfaction of telecommunication industries in Bangladesh.IOSR Journal of Business and Management (IOSRJBM), 8 (6), 80-86.

Taylor, F. W. (1911). The Principles of Scientific Management. Retrieved 30 th July2018, from Morden History sourcebook: http://www.fordham.edu/1911taylor.html

Tetty, J.W. (2006).Staff Retention in African Universities: Elements of a sustainable Bank.

Thomas, J. P., Whitman, D. S., \&Viswesvaran, C. (2010). Employee proactivity in organizations: A comparative meta - analysis of emergent proactive constructs. Journal of Occupational and Organizational Psychology, 83(2), 275-300.

Tungkiatsilp, A. (2013). The Effects of Job Characteristics and Job Satisfaction on Job Performance in the Restaurant Industry (Doctoral dissertation, Rajamangala University of Technology Thanyaburi.Faculty of Business Administration.Business Administration).

Unutmaz, S. (2014).Factors affecting job satisfaction of employees in a public.Unpublished MSc in Industrial Engineering, Middle East Technical University, Ankara, Turkey.

Walumbwa, F. O., Orwa, B., Wang, P., \& Lawler, J. J. (2005). Transformational leadership, organizational commitment, and job satisfaction: A comparative study of Kenyan and US financial firms. Human resource development quarterly, 16 (2), 235-256.

Welman, J. C., Kruger, S. J., \& Mitchell, B. (2013).Research Methodology (4 ${ }^{\text {th }}$ Ed.). Cape Town: Oxford University Press.

Welman, Kruger, \& Mitchell, (2008).Research methodology.(3rd Ed.). Cape Town: Oxford University.

Williams, M.L.,Brower,H.H.,Ford,L.R.,Williams,L.J.,\&Carraher,S.M.(2008).A comprehensive model and measures of compensation satisfaction. Journal of Occupational and Organizational Psychology, 81(4), 639-668.

Wright, B. \& Davis, B. (2003). Job satisfaction in the public sector: the role of the work Environment. American Review of Public Administration, 33 (1), 70-90.

Yamane, T. (1967).Statistics: An Introductory Analysis ( $2^{\text {nd }}$ Ed.) Harper and Row, New York.

Zeffane, R. (1994), Correlates of job satisfaction and their implications for work redesign, Public Personnel Management, 23 (1), 61-75. 